\title{
Cenozoic magmatic stages in
}

Sumatra and the incipient of Toba: Zircon ages and $\mathrm{Hf}$ isotope evidence

\author{
YU-Ming LAI ${ }^{1 *}$, PING-PING LIU ${ }^{2}$, AZMAN A. GHANI ${ }^{3}$, \\ HAO-YANG LEE ${ }^{4}$, SHAN LI $^{5}$, SAYED MURTADHA ${ }^{6}$, \\ LONG XIANG QUEK ${ }^{1}$, MuHAMMAd HATTA RoseleE ${ }^{3}$ \\ AND SUN-Lin CHUNG ${ }^{47}$ \\ ${ }^{1}$ Department of Earth Sciences, National Taiwan Normal \\ University, Taiwan (longxiang.quek@gmail.com, \\ correspondence: ymlai@ntnu.edu.tw) \\ ${ }^{2}$ School of Earth and Space Sciences, Peking University, \\ China (ppliu@pku.edu.cn) \\ ${ }^{3}$ Department of Geology, University of Malaya, Malaysia \\ (azmangeo@um.edu.my, hattarosley@yahoo.com) \\ ${ }^{4}$ Institute of Earth Sciences, Academia Sinica, Taiwan \\ (haoyanglee@earth.sinica.edu.tw) \\ ${ }^{5}$ Institute of Geology, Chinese Academy of Geological \\ Sciences, China (shanli@cags.ac.cn) \\ ${ }^{6}$ Department of Geology, Syiah Kuala University, Banda \\ Aceh, Indonesia (ali_madzhir@yahoo.com) \\ ${ }^{7}$ Department of Geosciences, National Taiwan University, \\ Taiwan (sunlin@ntu.edu.tw)
}

The Cenozoic magmatism in Sumatra island was formed by the Indo-Australian Plate subducted beneath the Eurasian Plate. Here we present zircon $\mathrm{U}-\mathrm{Pb}$ ages and $\mathrm{Hf}$ isotopes of 38 volcanic rocks and 18 plutonic rocks from Sumatra. Magmatic zircons show four stages in Cenozoic including (1) Palecocen to Early Eocene ( 66-48 Ma), (2) Middle Eocene to Miocene ( 48-23 Ma), (3) Miocene to Pliocene ( $23-2.6$ $\mathrm{Ma})$, and (4) Quaternary to Recenet ( 2.6-0 Ma). Four major flare-up events during 55-50 Ma, 25-20 Ma, 15-10 Ma, and 5-0 Ma can be observed with an obviously magmatic gap between 48-23 Ma. Comparing with ages and Hf isotopes, magmatism display different characteristics in the western Sumatra, Toba-related areas, central Sumatra, and eastern Sumatra. It is notable that only in the western Sumatra, magmatism suspended between 15-10 $\mathrm{Ma}$ and showed a temporal and sparial migration from southern to northern during that time. Except Toba-related samples show negtive $\varepsilon_{\mathrm{Hf}}(\mathrm{t})$ values, $\mathrm{Hf}$ isotopes in other areas show typical Sunda Arc ratios $\left(\varepsilon_{\mathrm{Hf}}(\mathrm{t})=+7\right.$ to +19$)$. The negtive $\varepsilon_{\mathrm{Hf}}(\mathrm{t})$ values can be found not only in the recent eruption of Toba, but also traceable to several events in $5 \mathrm{Ma}, 10 \mathrm{Ma}$, and $\sim 50 \mathrm{Ma}$ nearby Toba area. We suggest there might be some materials with enriched $\mathrm{Hf}$ isotopes beneath the Toba area since at least $\sim 50 \mathrm{Ma}$, and contributed to each stage of magmatism. These results provide a new idea of the incipient of recent Toba. 